Supporting Information for

\title{
Effects of Crowding and Environment on the Evolution of Conformational Ensembles of the Multi-stimuli Responsive Intrinsically Disordered Protein, Rec1-Resilin: A Small-Angle Scattering Investigation
}

Rajkamal Balu,,$^{\dagger}$ Jitendra P. Mata, ${ }^{\ddagger}$ Robert Knott,${ }^{\ddagger}$ Christopher M. Elvin ${ }^{\ddagger}$ Anita J. Hill,$^{\S}$ Namita R. Choudhury,

$3^{\circ}$ School of Chemical Engineering, The University of Adelaide, South Australia, Adelaide 5000, Australia.

${ }^{\dagger}$ Future Industries Institute, University of South Australia, Mawson Lakes, SA 5095, Australia.

${ }^{\ddagger}$ Bragg Institute, ANSTO, Private Mail Bag, Kirrawee, NSW 2232, Australia.

${ }^{{ }}$CSIRO Agriculture, Level 6, Queensland Bioscience Precinct, St Lucia, QLD 4067, Australia.

${ }^{\S}$ CSIRO Manufacturing, Bayview Ave, Clayton, VIC 3168, Australia.

*Corresponding authors E-mail: naba.dutta@adelaide.edu.au, naba.dutta@unisa.edu.au, Ph: +61 $883134116 ;+61883023546$, Mob: +61450042147 


\section{S1. Synthesis and Purification of Rec1-resilin}

For synthetic Rec1-resilin construct synthesis, CG15920 gene (exon-1, native resilin of the fruit fly Drosophila melanogaster) was cloned and expressed as a water soluble protein in the bacterium Escherichia coli. The expressed protein was extracted by cell disruption to obtain a yield of $\sim 300 \mathrm{mg} \mathrm{L}^{-1}$ of the culture. The obtained protein was purified by a three step nonchromatographic purification method involving salt precipitation (using 20\% ammonium sulphate), overnight dialysis at $4{ }^{\circ} \mathrm{C}$ (in excess phosphate-buffered saline, PBS) and heating at $80{ }^{\circ} \mathrm{C}$ for $10 \mathrm{~min}$ (with stirring). The denatured proteins were removed by centrifugation at $12,000 \mathrm{~g}$ for $15 \mathrm{~min}$ at $20{ }^{\circ} \mathrm{C}$ and the resulting protein solution in supernatant was vacuum dried at $40{ }^{\circ} \mathrm{C} .{ }^{1,2}$ 

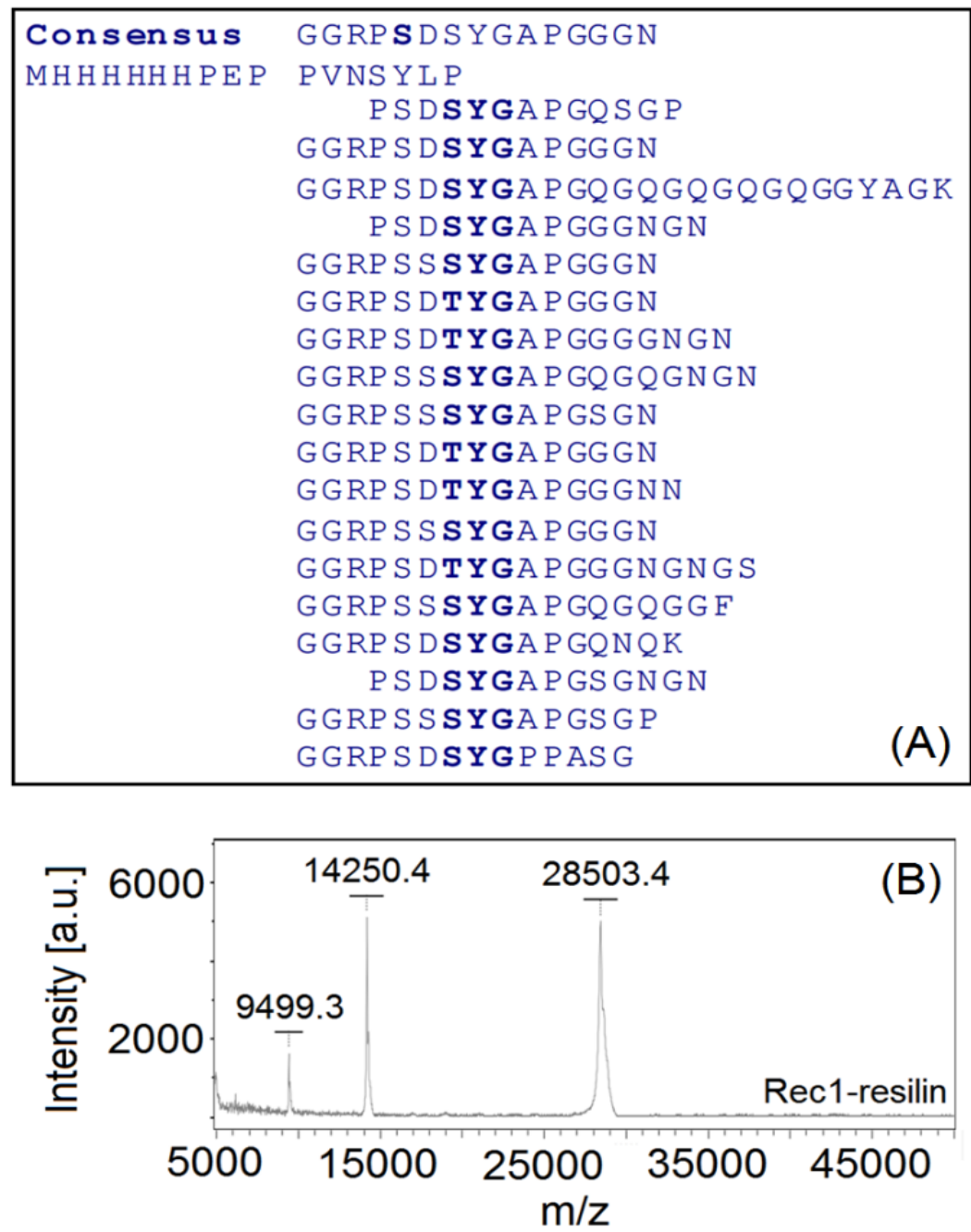

Figure S1. (A) Structural consensus and alignment of amino acid repeat sequence in Rec1resilin. ${ }^{1,2}$ Single-letter code is used. (B) MALDI-TOF mass spectra of synthesized Rec1-resilin. The three $\mathrm{m} / \mathrm{z}$ species (right to left) detected are the $[\mathrm{M}+\mathrm{H}]^{+},[\mathrm{M}+2 \mathrm{H}]^{2+}$, and $[\mathrm{M}+4 \mathrm{H}]^{4+}$ species of the protein. 

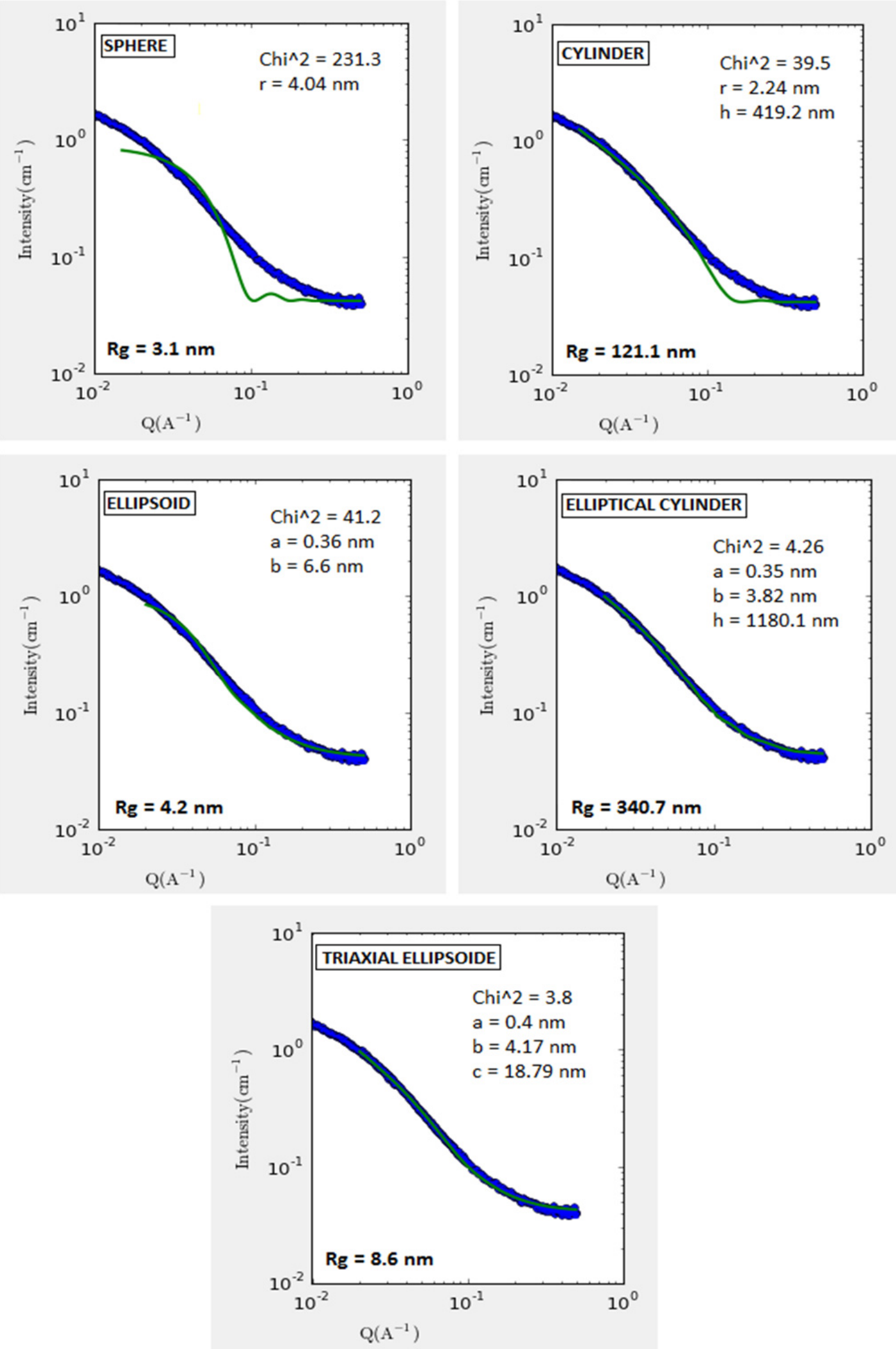

Figure S2. Typical computational model fits for the measured experimental SANS intensity profile of $10 \mathrm{wt} \%$ Rec1-resilin solution (at $\mathrm{pH} 7.4$ and $25^{\circ} \mathrm{C}$ ). The model used and the best fitting parameters including $\mathrm{R}_{\mathrm{g}}$ value obtained are given within each panel. 

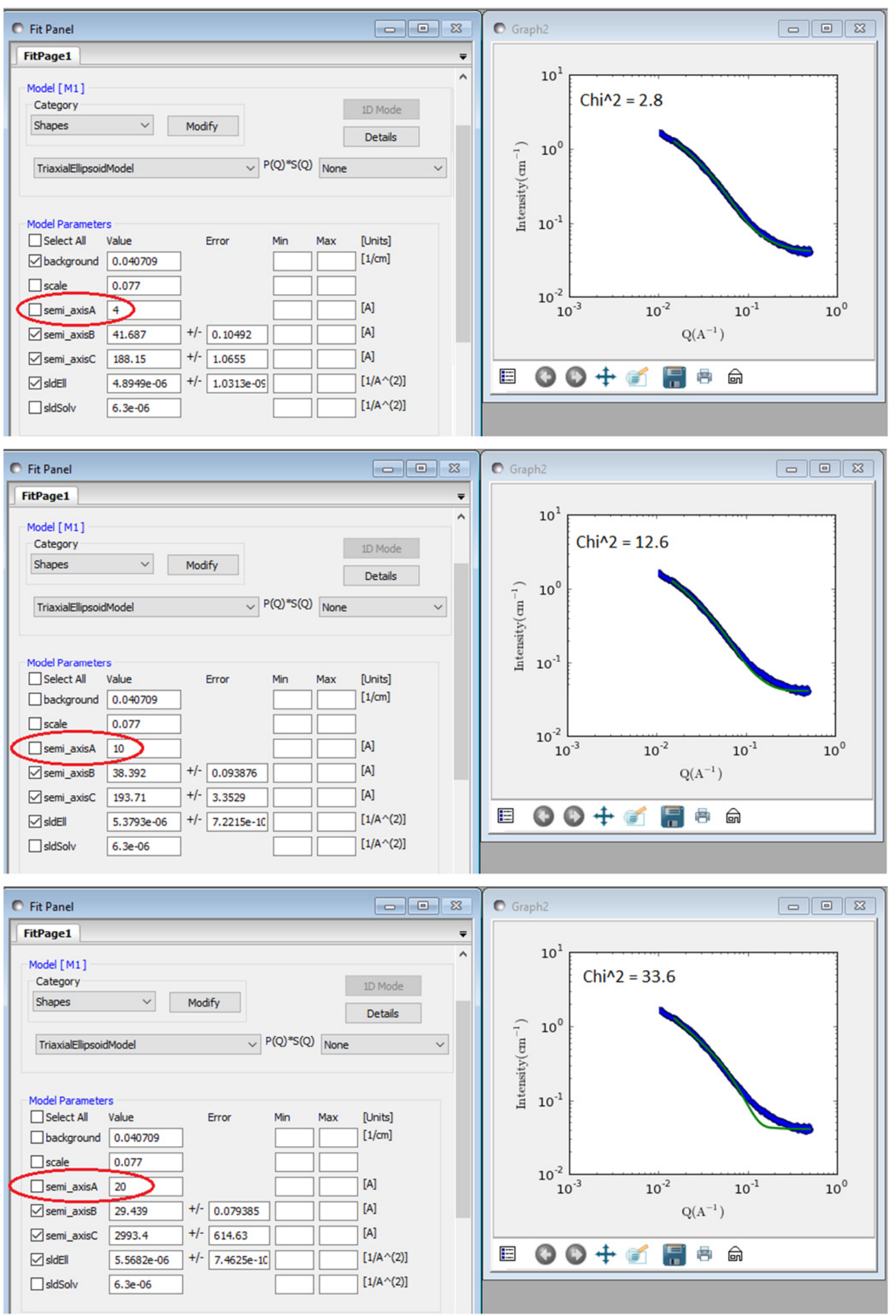

Figure S3. Triaxial ellipsoidal fits for the measured experimental SANS intensity profile of 10 $\mathrm{wt} \%$ Rec1-resilin solution (at $\mathrm{pH} 7.4$ and $25^{\circ} \mathrm{C}$ ) as a function of smaller semi axis A fit. Three typical semiaxis A value used and the quality of fitting obtained are shown. 
Table S1. Structural fit parameters of SANS intensity profile of $10 \mathrm{wt} \%$ Rec1-resilin as a function of structure factor at $\mathrm{pH} 7.4 ; 25^{\circ} \mathrm{C}$.

\begin{tabular}{|c|c|c|c|c|c|c|c|c|}
\hline \multirow{2}{*}{$\begin{array}{l}\text { Shape } \\
\text { independent } \\
\text { Gaussian } \mathbf{R}_{\mathrm{g}}\end{array}$} & \multirow{2}{*}{$\begin{array}{l}\text { Form } \\
\text { factor }\end{array}$} & \multirow{2}{*}{$\begin{array}{l}\text { Structure } \\
\text { factor }\end{array}$} & \multicolumn{6}{|c|}{ Triaxial ellipsoid fit } \\
\hline & & & $\begin{array}{l}\text { Semi } \\
\text { axis A } \\
(\mathrm{nm})\end{array}$ & $\begin{array}{l}\text { Semi } \\
\text { axis B } \\
(\mathrm{nm})\end{array}$ & $\begin{array}{l}\text { Semi } \\
\text { axis C } \\
(\mathrm{nm})\end{array}$ & $\begin{array}{l}\text { SLD } \\
\text { ellipse } \\
\left(10^{-6} / \AA^{2}\right)\end{array}$ & $\begin{array}{l}\mathbf{R}_{\mathrm{g}} \\
(\mathrm{nm})\end{array}$ & $\chi^{2}$ \\
\hline \multirow[t]{2}{*}{$8.2 \pm 0.01$} & \multirow[t]{2}{*}{$\begin{array}{l}\text { Triaxial } \\
\text { ellipsoid }\end{array}$} & None & 0.4 & $\begin{array}{l}4.2 \pm \\
0.01\end{array}$ & $\begin{array}{l}18.8 \pm \\
0.1\end{array}$ & 4.89 & 8.6 & 3.8 \\
\hline & & $\begin{array}{l}\text { Hayter } \\
\text { MSA* }\end{array}$ & 0.4 & $\begin{array}{l}7.8 \pm \\
0.05\end{array}$ & $\begin{array}{l}14.7 \pm \\
0.06\end{array}$ & 4.88 & 7.4 & 13.5 \\
\hline
\end{tabular}

* The Fourier transform of the pair correlation function $g(r)$ for a system of charged objects in a dielectric medium. 
Table S2. Amino acid composition of Rec1-resilin.*

\begin{tabular}{|c|c|c|c|c|}
\hline Amino acid residue & Amino acid residue & No of Unit & Molar Mass (\%) & Mol \% \\
\hline \multirow{9}{*}{ 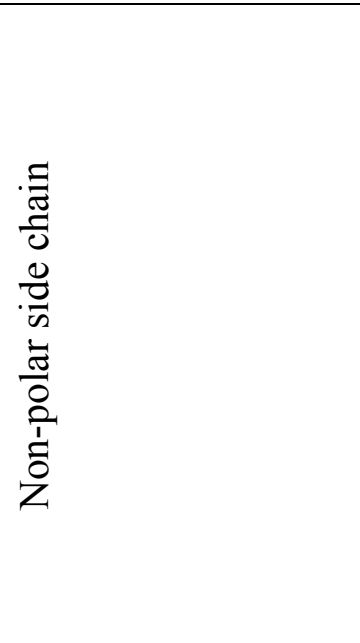 } & Gly & 107 & 23.58331 & 34.516 \\
\hline & Ala & 19 & 4.970193 & 6.129 \\
\hline & Val & 1 & 0.343958 & 0.322 \\
\hline & Leu & 2 & 0.385142 & 0.645 \\
\hline & Ile & 0 & 0 & 0 \\
\hline & Met & 1 & 0.438089 & 0.322 \\
\hline & Pro & 43 & 14.53568 & 13.870 \\
\hline & Phe & 1 & 0.48502 & 0.322 \\
\hline & Try & 0 & 0 & 0 \\
\hline \multirow{6}{*}{ 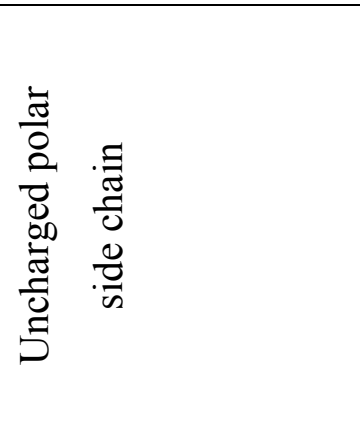 } & Ser & 44 & 13.57686 & 14.193 \\
\hline & Thr & 5 & 1.748747 & 1.612 \\
\hline & Asn & 20 & 7.758298 & 6.451 \\
\hline & Gln & 12 & 5.149191 & 3.870 \\
\hline & Tyr & 20 & 10.63992 & 6.451 \\
\hline & Cys & 0 & 0 & 0 \\
\hline \multirow{6}{*}{ 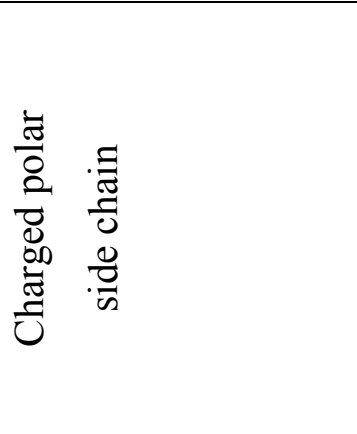 } & Lys & 2 & 0.858453 & 0.645 \\
\hline & Arg & 15 & 7.672153 & 4.838 \\
\hline & His & 6 & 2.733328 & 1.935 \\
\hline & Asp & 12 & 4.689676 & 3.870 \\
\hline & Glu & 1 & 0.431991 & 0.322 \\
\hline & & 310 & $100 \%$ & $100 \%$ \\
\hline
\end{tabular}

*Three-letter code is used to represent each amino acid residues. 


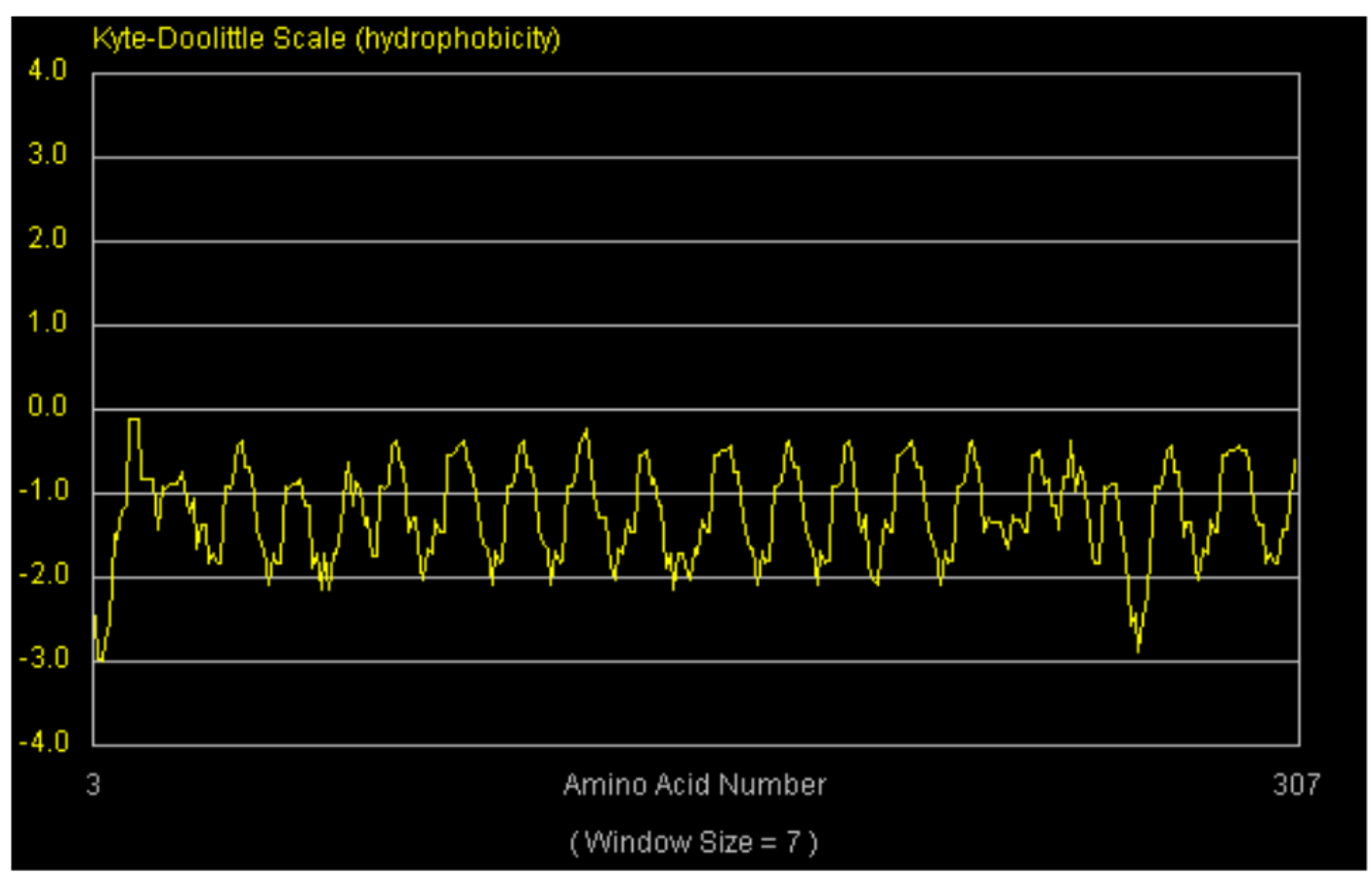

Figure S4 Kyte-Doolittle ${ }^{3,4}$ hydropathy plot of Rec1-resilin sequence using window size 7 (the number of amino acids whose hydrophobicity is averaged and assigned to the first amino acid in the window). The values above zero reflect hydrophobicity of the protein surface. All the regions of Rec1-resilin exhibit values below zero reflecting the hydrophilicity of the protein surface. 


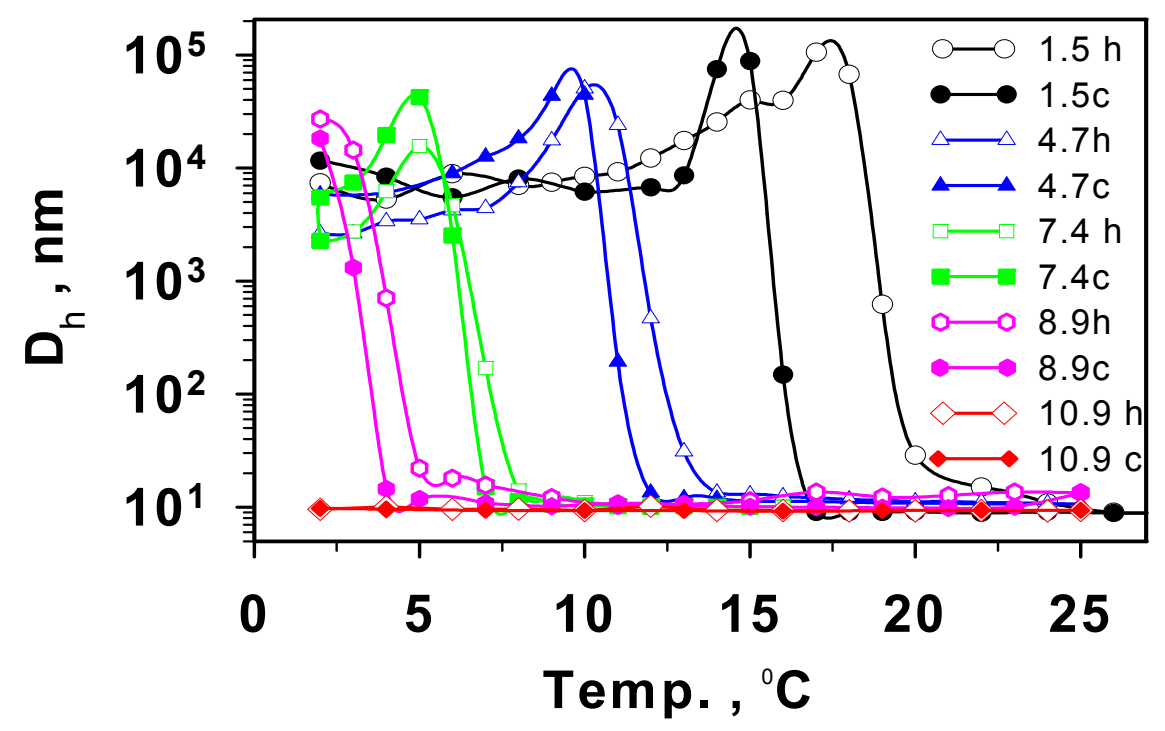

Figure S5. Plot of the hydrodynamic radius, $\mathrm{D}_{\mathrm{h}}$ of Rec1-resilin as a function of temperature at different $\mathrm{pH}$. $\mathrm{D}_{\mathrm{h}}$ was measured using a Dynamic light scattering. Both heating (h) and cooling curves (c) at different experimental $\mathrm{pH}$ are shown. Effect of $\mathrm{pH}$ on the UCST -indicated by sharp increase in $\mathrm{D}_{\mathrm{h}^{-}}$of a $10 \mathrm{mg} \mathrm{ml}^{-1}$ solution of Rec1-resilin is clearly demonstrated in the figure. UCST shifts progressively to higher temperature with decreasing $\mathrm{pH}$. At $\mathrm{pH} 10.9$ the solution ceased to exhibit UCST. The charge neutralization on the branch of $\mathrm{Arg}$ at higher $\mathrm{pH}$ helps to reduce self association related to the interaction between zwitterionic Arg/Asp amino acid pairs, though the rest of the Arg side chain is composed of hydrophobic methylene groups contribute favourably to self-assembling. 


\section{References}

(1) Elvin, C. M.; Carr, A. G.; Huson, M. G.; Maxwell, J. M.; Pearson, R. D.; Vuocolo, T.; Liyou, N. E.; Wong, D. C. C.; Merritt, D. J.; Dixon, N. E. Synthesis and Properties of Crosslinked Recombinant Pro-Resilin. Nature 2005, 437, 999-1002.

(2) Lyons, R. E.; Lesieur, E.; Kim, M.; Wong, D. C. C.; Huson, M. G.; Nairn, K. M.; Brownlee, A. G.; Pearson, R. D.; Elvin, C. M. Design and Facile Production of Recombinant Resilin-Like Polypeptides: Gene Construction and a Rapid Protein Purification Method. Protein Eng. Des. Sel. 2007, 20, 25-32.

(3) Kyte, J.; Doolittle, R. A Simple Method for Displaying the Hydropathic Character of a Protein. J. Mol. Biol. 1982, 157, 105-132.

(4) https://ebbailey.wordpress.com/hydropathicity-plots/ 